\title{
VALIDATED STABILITY INDICATING HPLC APPROACH FOR QUANTIFYING TRICHOLINE CITRATE AND CYPROHEPTADINE SIMULTANEOUSLY IN SYRUP FORMS
}

\author{
MOHINISH SAHAI ${ }^{*}$, N. DEVANNA ${ }^{2}$
}

${ }^{1}$ Department of Chemistry, JNTU Anantapur, Andhra Pradesh, India, ${ }^{2}$ Director, OTRI, JNTU Anantapur, Andhra Pradesh, India Email: mohinish_sahai@rediffmail.com

Received: 24 Jan 2021, Revised and Accepted: 02 Apr 2021

\section{ABSTRACT}

Objective: This investigation demonstrates a stability-indicating and reliable "high-performance liquid chromatography" method to simultaneously quantify tricholine citrate (TEC) and cyproheptadine (CRH) in the syrup form and bulk form.

Methods: Successful separation was accomplished using C18 "Agilent column (250 mm $\times 4.6 \mathrm{~mm}, 5 \mu \mathrm{m})$ " with isocratic type of elution using mobile phase containing $0.1 \mathrm{M} \mathrm{NaH}_{2} \mathrm{PO}_{4}$ buffer and acetonitrile at $55 \%$ volume and $45 \%$ volume ratio, respectively with $1.0 \mathrm{ml} / \mathrm{min}$ flow rate. The wavelength sensor was attuned at $263 \mathrm{~nm}$ to quantify TEC and CRH.

Results: TEC and CRH peaks were eluted with fine resolution at retention times $1.837 \mathrm{~min}$ and $2.936 \mathrm{~min}$, respectively. In the $137.5-412.5 \mu \mathrm{g} / \mathrm{ml}$ and $1-3 \mu \mathrm{g} / \mathrm{ml}$ concentration ranges for TEC and CRH, the calibration graphs were linear, with regression coefficients of 0.9999 and 0.9998 , respectively. The suggested "high-performance liquid chromatography" approach has been shown as sensitive, precise, robust, accurate, specific and stability indicating through the resolution of TEC and CRH from its degradation-based compounds.

Conclusion: The established high-performance liquid chromatography technique was effectively extended to the evaluation of TEC and CRH in the combined syrup form and the test results appeared satisfactory.

Keywords: Tricholine citrate, Cyproheptadine, Syrup form, HPLC, Stability indicating

(c) 2021 The Authors. Published by Innovare Academic Sciences Pvt Ltd. This is an open access article under the CC BY license (https://creativecommons.org/licenses/by/4.0/) DOI: https://dx.doi.org/10.22159/ijap.2021v13i3.40871. Journal homepage: https://innovareacademics.in/journals/index.php/ijap

\section{INTRODUCTION}

Tricholine Citrate (TEC) is recommended in the adults to treat and control hepatic and pancreatic disorders [1-3]. In hepatic cells, TEC confers lipotropic behaviour. TEC can also alleviate asthma complications and reduce the leukotriene pathway's proinflammatory and also inflammatory mediators. Chemically, TEC is described as 2-hydroxy-N,N,N-trimethylethanaminium 2hydroxyproline-1,2,3-tricarboxylate (fig. 1). Cyproheptadine (CRH) relieves irritated, red, itchy, watery eyes, sneezing, and runny nose triggered by irritants present in air, allergies and hay fever [4-6]. CRH can often be used to relieve itching of allergic skin conditions and also to treat rashes, including rashes due to cold temperature stimulation and skin rubbing. CRH is in a category of medicines recognized as antihistamines. $\mathrm{CRH}$ functions by suppressing the activity of histamine, a material that triggers body's allergic reactions. Chemically $\mathrm{CRH}$ is described as 4- $(5 \mathrm{H}$ Dibenzo[a,d]cyclohepten-5-ylidene)-1-methylpiperidine (fig. 1).<smiles>CCOCC[N+](C)(C)C</smiles>

Tricholine citrate

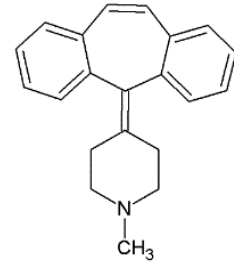

Cyproheptadine

Fig. 1: Structures of drugs

Combination therapies become part of the standardized testing of all drugs and the treatment of all diseases [7-10]. A combination treatment is a therapeutic approach in which the patient is given more than one treatment. Cases of combination therapies include treatments that involve the treatment with many different medications, each comprising a specific drug, or the single medication containing several drugs.

The combination of TEC and CRH is available as a syrup formulation [11-15]. The TEC and CRH combination therapy increases appetite, offers the efficient hepato-protective operation, guarantees weight gaining and boosts protein synthesis. Combination treatment with TEC and CRH is prescribed for the hepatobiliary conditions linked with anorexia, leading to weight reduction [16]. To the maximum of our awareness, no procedures for measuring the combination of TEC and $\mathrm{CRH}$ in syrup preparations have been established yet. This paper proposes a novel sensitive stability-indicating HPLC procedure for the assessment of TEC and CRH combination. The process proposed enables the rapid assessment of the mixture of TEC and CRH in bulk drugs and syrup preparations without sample pretreatment with high precision and specificity, and with no excipient intervention.

\section{MATERIALS AND METHODS}

Chemicals

$\mathrm{NaH}_{2} \mathrm{PO}_{4}, \mathrm{HCl}, \mathrm{NaOH}, \mathrm{H}_{2} \mathrm{O}_{2}$ and orthophosphoric acid were acquired from "Sd Fine Chemicals Ltd, India". Acetonitrile was acquired from "Merck India Ltd, India". TEC and CRH bulk samples were gifted from "Rainbow pharma training labs, India". Cypro $\mathrm{T}$ formulation 
syrup from "Nexkem Pharmaceutical, India" with labelled claim of 2 $\mathrm{mg}$ CRH and $275 \mathrm{mg}$ TEC was utilized.

\section{Instrument and evaluation conditions}

Separations and analyses of TEC and CRH were accomplished using Waters chromatograph (2695) system furnished with Waters photodiode (2998) detector. The column employed was "Agilent C18 $(250 \mathrm{~mm} \times 4.6 \mathrm{~mm}$ and $5 \mu \mathrm{m}$ )" with room temperature. Mobile phase employed was a combination of $0.1 \mathrm{M} \mathrm{NaH}_{2} \mathrm{PO}_{4}$ buffer and acetonitrile at $55 \%$ volume and $45 \%$ volume ratio, respectively with $1.0 \mathrm{ml} / \mathrm{min}$ flow rate. The buffer's $\mathrm{pH}$ was tuned at 4.0 value with $0.1 \%$ orthophosphoric acid. The mobile phase was degassed and filtered before utilization through degasser and $0.45 \mu \mathrm{m}$ membrane filters, respectively. The peak area intensity of TEC and CRH was measured at $263 \mathrm{~nm}$ with the injection size volume of $10 \mu \mathrm{l}$.

\section{Standard TEC and CRH solution}

Standard TEC and CRH solution containing $2750 \mu \mathrm{g} / \mathrm{ml}$ (TEC) and 20 $\mu \mathrm{g} / \mathrm{ml}(\mathrm{CRH})$ was prepared by dissolving $275 \mathrm{mg}$ of TEC and $2 \mathrm{mg}$ of CRH in $100 \mathrm{ml}$ of mobile phase solvent blend. The standard TEC and $\mathrm{CRH}$ solution were diluted employing mobile phase solvent blend further as needed.

\section{Procedures}

\section{Calibration graphs of TEC and CRH}

Accurately assessed aliquot parts of the standard TEC and CRH were moved to a set of $10 \mathrm{ml}$ volumetric bottles such that the ultimate concentrations were between 137.5-412.5 $\mu \mathrm{g} / \mathrm{ml}$ (TEC) and 1-3 $\mu \mathrm{g} / \mathrm{ml}(\mathrm{CRH})$. The solutions are finished to volume employing mobile phase solvent blend and blended well. Samples of $10 \mu$ l volume were infused and eluted under optimal chromatographic constraints with the mobile phase solvent blend. The analyte peak areas against the ultimate drug concentrations were plotted. The related regression equations for TEC and CRH were alternatively derived.

\section{Analysis of TEC and CRH in the Cypro T formulation syrup}

A measured volume ( $5 \mathrm{ml}$ ) of syrup equivalent to $2 \mathrm{mg} \mathrm{CRH}$ and 275 $\mathrm{mg}$ TEC was moved to $100 \mathrm{ml}$ volumetric bottle, about $75 \mathrm{ml}$ of mobile phase solvent blend was included and sonicated $30 \mathrm{~min}$ to dissolve TEC and CRH. The solution then was mobile phase-diluted to volume, blended and filtered. Aliquot consisting of concentration $2 \mu \mathrm{g} / \mathrm{ml}$ of CRH and $275 \mu \mathrm{g} / \mathrm{ml}$ of TEC was moved to a $10 \mathrm{ml}$ volumetric bottle. The process described under "Calibration graphs of TEC and CRH" was executed. The nominal contents of TEC and $\mathrm{CRH}$ in Cypro $\mathrm{T}$ formulation syrup were evaluated either from related calibration graph or from related regression equation.

\section{Procedures for TEC and CRH stability studies}

In compliance with ICH recommendations, the stability studies on Cypro T formulation solution were done [17].

\section{Degradation using alkaline}

Volume $(10 \mathrm{ml})$ of Cypro $\mathrm{T}$ formulation solution containing 2750 $\mu \mathrm{g} / \mathrm{ml}$ (TEC) and $20 \mu \mathrm{g} / \mathrm{ml}$ (CRH) was moved to $100 \mathrm{ml}$ volumetric bottle; $10 \mathrm{ml}$ aliquot part of $0.1 \mathrm{~N} \mathrm{NaOH}$ solution was included. The solution stayed sonicated $30 \mathrm{~min}$ at room temperature. After specified $30 \mathrm{~min}$ time, the contents of volumetric bottle were cooled, neutralized using $0.1 \mathrm{~N} \mathrm{HCl}$. The solution then was mobile phasediluted to volume, blended and filtered. The process described under "Calibration graphs of TEC and CRH" was executed. The assay and degradation percentage of TEC and CRH were evaluated.

\section{Degradation using acid}

Volume $(10 \mathrm{ml})$ of Cypro T formulation solution containing 2750 $\mu \mathrm{g} / \mathrm{ml}$ (TEC) and $20 \mu \mathrm{g} / \mathrm{ml}$ (CRH) was moved to $100 \mathrm{ml}$ volumetric bottle; $10 \mathrm{ml}$ aliquot part of $0.1 \mathrm{~N} \mathrm{HCl}$ solution was included. The solution stayed sonicated $30 \mathrm{~min}$ at room temperature. After specified 30 min time, the contents of volumetric bottle were cooled, neutralized using $0.1 \mathrm{~N} \mathrm{NaOH}$. The solution then was mobile phase- diluted to volume, blended and filtered. The process mentioned under "TEC and CRH calibration graphs" has been implemented. TEC and $\mathrm{CRH}$ were tested for the assay and degradation percentage.

\section{Degradation using peroxide}

Volume $(10 \mathrm{ml})$ of Cypro $\mathrm{T}$ formulation solution containing 2750 $\mu \mathrm{g} / \mathrm{ml}$ (TEC) and $20 \mu \mathrm{g} / \mathrm{ml}$ (CRH) was moved to $100 \mathrm{ml}$ volumetric bottle; $10 \mathrm{ml}$ aliquot part of $30 \%$ peroxide solution was included. The solution stayed sonicated $30 \mathrm{~min}$ at room temperature. After specified 30 min time, the solution then was mobile phase-diluted to volume, blended and filtered. The process described under "Calibration graphs of TEC and CRH" was executed. The assay and degradation percentage of TEC and CRH were evaluated.

\section{Degradation using sun light}

Volume $(10 \mathrm{ml})$ of Cypro $\mathrm{T}$ formulation solution containing 2750 $\mu \mathrm{g} / \mathrm{ml}$ (TEC) and $20 \mu \mathrm{g} / \mathrm{ml}$ (CRH) was moved to $100 \mathrm{ml}$ volumetric bottle. The bottle with Cypro T formulation solution was lay open to sun light for a time of $6 \mathrm{hr}$. After specified $6 \mathrm{hr}$ time, the solution then was mobile phase-diluted to volume, blended and filtered. The process described under "Calibration graphs of TEC and CRH" was executed and followed by evaluation of assay and degradation percentage of TEC and CRH.

\section{Degradation using dry heat}

Volume $(10 \mathrm{ml})$ of Cypro $\mathrm{T}$ formulation solution containing 2750 $\mu \mathrm{g} / \mathrm{ml}$ (TEC) and $20 \mu \mathrm{g} / \mathrm{ml}$ (CRH) was moved to $100 \mathrm{ml}$ volumetric bottle. The bottle with Cypro $\mathrm{T}$ formulation solution was wide-open to $60^{\circ} \mathrm{C}$ in oven for a time of $30 \mathrm{~min}$. After specified $30 \mathrm{~min}$ time, the solution then was mobile phase-diluted to volume, blended and filtered. The assay and degradation percentage of TEC and CRH were evaluated employing process explained under "Calibration graphs of TEC and CRH".

\section{RESULTS}

\section{Validation of procedure}

In acquiescence with ICH recommendations, the validity parameters were established [18].

\section{Linearity}

During this work, the linearity of area response was checked for both TEC and CRH. Chromatographed solutions with concentrations of $137.5-412.5 \mu \mathrm{g} / \mathrm{ml}$ for TEC and $1-3 \mu \mathrm{g} / \mathrm{ml}$ for CRH given linear peak response areas. The regression line equation, regression coefficient and TEC and CRH calibration curves are shown in fig. 2 .

\section{Limits of quantification (Lq) and detection (Ld)}

Both Lq and Ld were measured utilizing a signal-to-noise methodology. Lq and Ld were defined as the TEC an CRH concentration levels that ensuing a peak height of 10 times and 3 times, respectively the baseline noise. The Ld and Lq were found to be $0.124 \mu \mathrm{g} / \mathrm{ml}$ and $0.413 \mu \mathrm{g} / \mathrm{ml}$, respectively, for TEC and 0.0023 $\mu \mathrm{g} / \mathrm{ml}$ and $0.0078 \mu \mathrm{g} / \mathrm{ml}$, respectively, for CRH.

\section{Accuracy and precision}

The accuracy and precision measurements were assessed using measurements of TEC and CRH solution $(2 \mu \mathrm{g} / \mathrm{ml}$ and $275 \mu \mathrm{g} / \mathrm{ml})$ repeated six times within the day. The precision was validated by the RSD measurements of the TEC and CRH peak areas, while the accuracy was validated by the TEC and CRH percentage content assays (table 1).

\section{Recovery}

The recovery was determined by assay of TEC and CRH in spiked Cypro $\mathrm{T}$ samples according to proposed method. Three diverse quantities (50\% quantity degree, $100 \%$ quantity degree and $150 \%$ quantity degree) of TEC and CRH standards were put into Cypro T samples. The recovered values of TEC and CRH were presented in table 2 . 

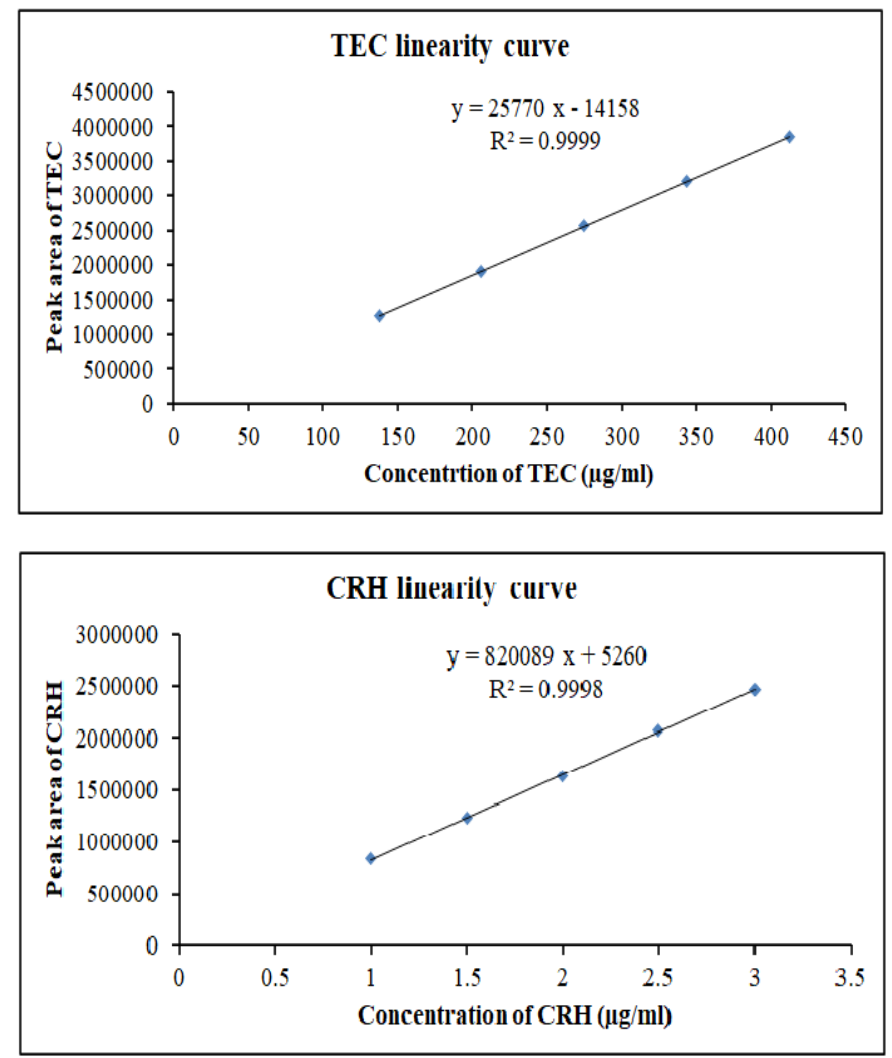

Fig. 2: TEC and CRH linearity curves

Table 1: Precision and accuracy measurements for TEC and CRH

\begin{tabular}{|c|c|c|c|c|}
\hline \multirow[t]{2}{*}{ Sample No. } & \multicolumn{2}{|l|}{ Precision } & \multicolumn{2}{|l|}{ Accuracy } \\
\hline & TEC area & CRH area & TEC \% assay & CRH \% assay \\
\hline 1 & 2581692 & 1673134 & 99.48 & 100.60 \\
\hline 2 & 2586089 & 1673918 & 99.65 & 100.65 \\
\hline 3 & 2610132 & 1680554 & 100.58 & 101.05 \\
\hline 4 & 2599406 & 1661186 & 100.17 & 99.88 \\
\hline 5 & 2595038 & 1664656 & 100.00 & 100.09 \\
\hline 6 & 2587896 & 1680666 & 99.72 & 101.05 \\
\hline Avg. & 2593375.50 & 1672352.33 & 99.93 & 100.55 \\
\hline S. D & 10387.8131 & 8041.9805 & 0.4025 & 0.4843 \\
\hline R.S. D & 0.4006 & 0.4809 & 0.4027 & 0.4817 \\
\hline
\end{tabular}

Avg.-mean of six measurements; SD-Deviation of value for six measurements; RSD-Percentage deviation

Table 2: Recoveries of TEC and CRH

\begin{tabular}{|c|c|c|c|c|c|}
\hline Spiked degree (\%) & Quantity added $(\mu \mathrm{g} / \mathrm{ml})$ & Quantity quantified* $(\mu \mathrm{g} / \mathrm{ml})$ & Quantity recovered* $(\%)$ & SD & RSD \\
\hline 50 & 136.125 & 134.90 & 99.10 & 0.4912 & 0.496 \\
\hline 100 & 272.2 & 271.88 & 99.86 & 0.1815 & 0.182 \\
\hline 150 & 408.375 & 408.88 & 100.12 & 0.0702 & 0.070 \\
\hline 50 & 0.99 & 0.99 & 100.42 & 0.0656 & 0.065 \\
\hline 100 & 1.98 & 1.97 & 99.53 & 0.3932 & 0.395 \\
\hline 150 & 2.97 & 2.96 & 99.71 & 0.1015 & 0.102 \\
\hline
\end{tabular}

${ }^{*}$ mean of three measurements; SD-Deviation of value for three measurements; RSD-Percentage deviation

\section{Robustness}

The robustness was measured using peak area measurements of TEC and CRH solution ( $2 \mu \mathrm{g} / \mathrm{ml}$ and $275 \mu \mathrm{g} / \mathrm{ml}$ ) with considerably changed parameters in HPLC assay operating conditions. The changed parameters and peak areas obtained were presented in table 3.

\section{Selectivity}

To prove selectivity, a comparison of blank (mobile phase solvent blend), TEC and CRH solution $(2 \mu \mathrm{g} / \mathrm{ml}$ and $275 \mu \mathrm{g} / \mathrm{ml})$ and Cypro T sample $(2 \mu \mathrm{g} / \mathrm{ml}$ and $275 \mu \mathrm{g} / \mathrm{ml})$ chromatograms were made. The respective chromatograms were given away in fig. 3. 
Sahai et al.

Table 3: Robustness of assay of TEC and CRH

\begin{tabular}{|c|c|c|c|c|c|c|c|}
\hline \multirow[t]{2}{*}{ Parameter } & \multirow{2}{*}{$\begin{array}{l}\text { Condition } \\
\text { employed }\end{array}$} & \multicolumn{3}{|l|}{ TEC } & \multicolumn{3}{|l|}{ CRH } \\
\hline & & Peak area & SD & RSD & Peak area & SD & RSD \\
\hline \multirow{3}{*}{$\begin{array}{l}\text { Acetonitrile volume } \\
(\%)\end{array}$} & 40 & 2598351 & 40645.7451 & 1.585 & 1682281 & 30050.9462 & 1.816 \\
\hline & 45 & 2576531 & & & 1659686 & & \\
\hline & 50 & 2519624 & & & 1622752 & & \\
\hline \multirow[t]{3}{*}{ Flow rate $(\mathrm{ml} / \mathrm{min})$} & 0.9 & 2524231 & 42473.4756 & 1.653 & 1620685 & 31160.0151 & 1.884 \\
\hline & 1.0 & 2576531 & & & 1659686 & & \\
\hline & 1.1 & 2608351 & & & 1682281 & & \\
\hline \multirow[t]{3}{*}{$\mathrm{pH}$} & 3.8 & 2573576 & 2122.9900 & 0.082 & 1653039 & 3565.5242 & 0.215 \\
\hline & 4.0 & 2576531 & & & 1659686 & & \\
\hline & 4.2 & 2572413 & & & 1654126 & & \\
\hline \multirow{3}{*}{$\begin{array}{l}\text { Wavelength } \\
(\mathrm{nm})\end{array}$} & 261 & 2503577 & 36537.1568 & 1.439 & 1685964 & 31122.2638 & 1.879 \\
\hline & 263 & 2576531 & & & 1659686 & & \\
\hline & 265 & 2536424 & & & 1623959 & & \\
\hline \multirow{3}{*}{$\begin{array}{l}\text { Temperature } \\
\left({ }^{\circ} \mathrm{C}\right)\end{array}$} & 23 & 2539624 & 29307.7494 & 1.140 & 1632752 & 23092.1729 & 1.394 \\
\hline & 25 & 2576531 & & & 1659686 & & \\
\hline & 27 & 2597514 & & & 1678710 & & \\
\hline
\end{tabular}

SD-Deviation of value for three peak area measurements; RSD-Percentage deviation
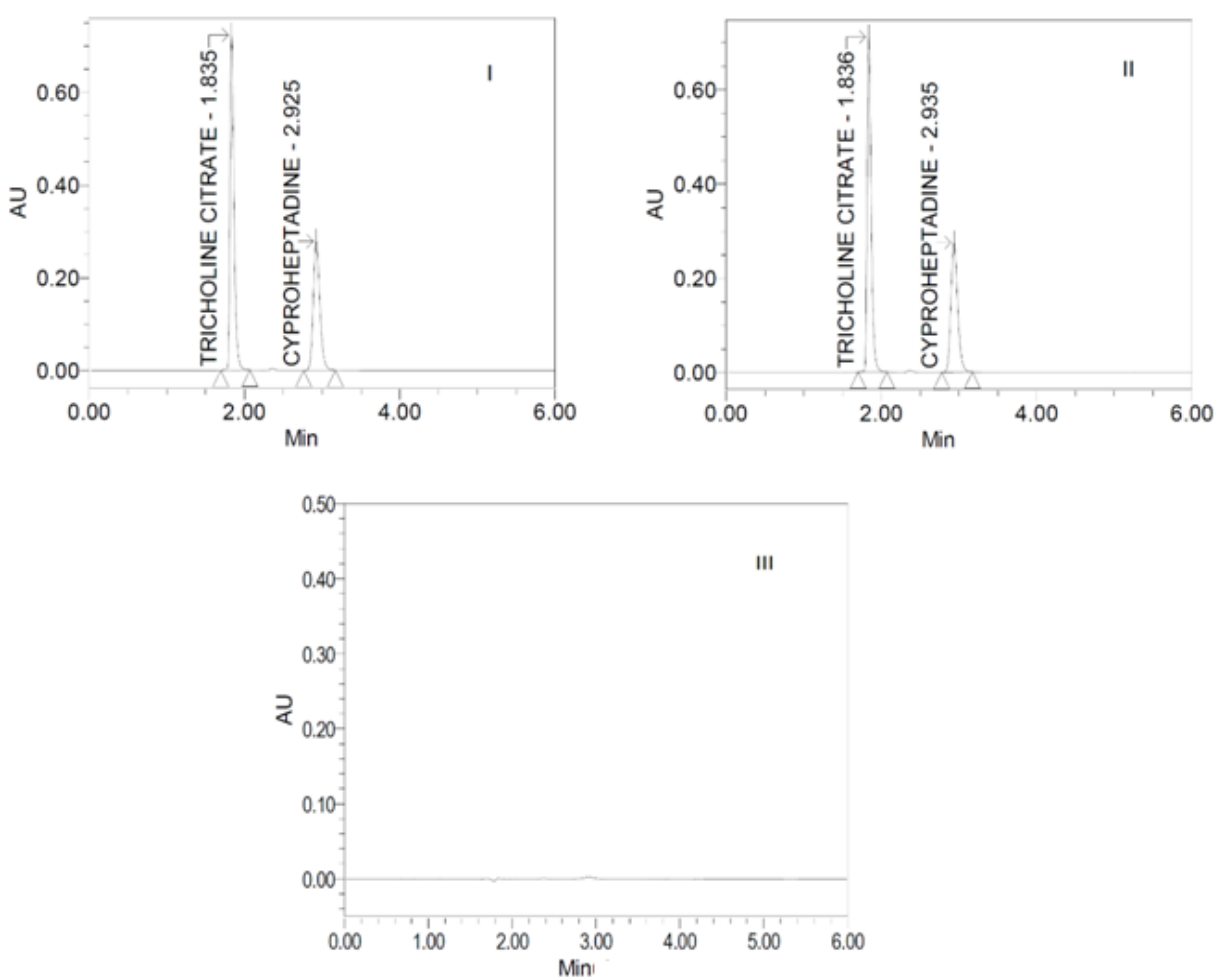

Fig. 3: Obtained chromatograms for (I) Cypro T sample (II) TEC an CRH solution (III) Blank

\section{Degradation study and specificity}

These investigations have been completed to explicate the intrinsic stability capabilities of TEC and CRH in combination under distinct situations of forced degradation described earlier. By using $0.1 \mathrm{~N} \mathrm{HCl}$, $30 \%$ peroxide and dry heat, TEC percent recovery was decreased about $11.69 \%, 6.74 \%$ and $7.32 \%$, respectively while $\mathrm{CRH}$ percent recovery was decreased about $8.42 \%, 4.97 \%$ and $6.52 \%$, respectively. The chromatograms corresponding to TEC and $\mathrm{CRH}$ in $0.1 \mathrm{~N} \mathrm{HCl}, 30 \%$ peroxide and dry heat degradation were shown in fig. 4. I, 4. II and 4. III. In sunlight and $0.1 \mathrm{~N} \mathrm{NaOH}$ conditions, TRH percent recovery was decreased about $9.08 \%$ and $5.36 \%$, respectively and CRH was decreased by about $10.94 \%$ and $7.77 \%$, respectively. The chromatograms corresponding to TEC and CRH in sunlight and $0.1 \mathrm{~N}$ $\mathrm{NaOH}$ degradation conditions were displayed in fig. 4 . IV and 4. V. The additional peaks generated, in the course of $0.1 \mathrm{~N} \mathrm{HCl}, 30 \%$ peroxide, dry heat, sunlight and $0.1 \mathrm{~N} \mathrm{NaOH}$ conditions applied, resolved finely from the TEC and CRH peaks (fig. 4. I to 4. V).

\section{System suitability}

The system suitability measurements were assessed using measurements of TEC and CRH solution ( $2 \mu \mathrm{g} / \mathrm{ml}$ and $275 \mu \mathrm{g} / \mathrm{ml}$ ) repeated five times. The system suitability was validated by measurements of plate counts, tailing symmetry, resolution, retention time and peak areas for the TEC and CRH peak (table 4). 

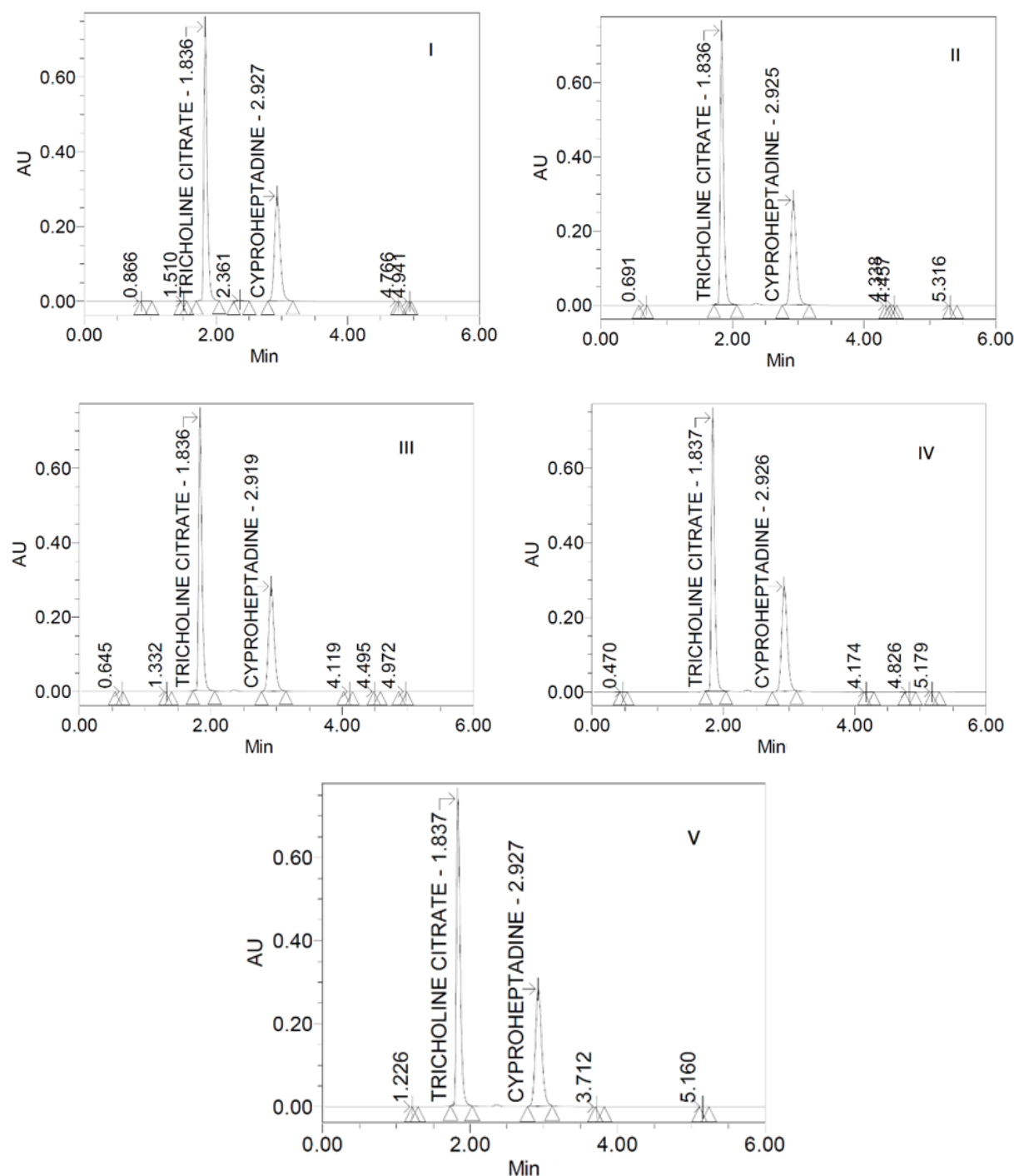

Fig. 4: Obtained chromatograms for degradation with (I) $0.1 \mathrm{~N} \mathrm{HCl} \mathrm{(II)} 30 \%$ peroxide (III) Dr heat (IV) Sun light (V) $0.1 \mathrm{~N} \mathrm{NaOH}$

Table 4: System suitability for assay of TEC and CRH

\begin{tabular}{lllll}
\hline Statistical data & Retention period (min) & Area & Resolution & Plate count \\
\cline { 2 - 5 } & TEC & & & Tailing \\
\hline Avg. & 1.837 & 2582140 & - & 6173 \\
SD & 0.0011 & 8718.8306 & - & 125.6523 \\
RSD & 0.060 & 0.338 & - & 2.036 \\
Avg. & CRH & 1656492 & & 0.0130 \\
SD & 2.936 & 5194.4251 & 0.560 & 5625 \\
RSD & 0.0020 & 0.314 & 0.0361 & 39.4614 \\
\hline
\end{tabular}

Avg.-mean of five measurements; SD-Deviation of value for five measurements; RSD-Percentage deviation

\section{DISCUSSION}

To quantify CRH methods like spectrofluorimetry (by Belal et al.,) [19], UV spectrophotometry (by Wagh et al.,) [20], colorimetry (by Sayanna et al.,) [21], HPLC (by Maham et al., Sadhana et al., Mina et al., El-Din et al.,) [22-25] and LC-MS (Feás et al.,) [26] were reported. To quantity TEC no reports were found. Similarly, no procedures for measuring the combination of TEC and CRH in syrup preparations have been established yet. This paper proposes a novel sensitive stability-indicating HPLC procedure for the assessment of TEC and CRH combination.

At the time of developmental trials, different C18 columns like YMC, Xterra, Waters and Agilent were investigated. The YMC and Xterra have dimensions of $150 \mathrm{~mm}$ length, $4.6 \mathrm{~mm}$ identification and $5 \mu \mathrm{m}$ particle size. The Waters and Agilent have dimensions of $250 \mathrm{~mm}$ length, $4.6 \mathrm{~mm}$ identification and $5 \mu \mathrm{m}$ particle size. As a mobile phase solvent blend, various solvent blends of different proportions have been checked. They include $0.1 \mathrm{M} \mathrm{K}_{2} \mathrm{HPO}_{4}$ : methanol, $0.1 \mathrm{M}$ $\mathrm{Na}_{2} \mathrm{HPO}_{4}$ : acetonitrile and $0.1 \mathrm{M} \mathrm{NaH} 2 \mathrm{PO}_{4}$ : acetonitrile. Resolution of TEC and CRH peaks was acceptable with C18 Aligent column at ambient temperature. $0.1 \mathrm{M} \quad \mathrm{NaH}_{2} \mathrm{PO}_{4}$ with $4 \mathrm{pH}$ value and acetonitrile at the proportion of $55 \%$ volume and $45 \%$ volume [23], respectively, were optimized for the finest TEC and CRH peak shape and less retention time [23-26] for this proposed chromatographic process. To rapidly separate TEC and CRH, an isocratic elution mode 
with $1.0 \mathrm{ml} / \mathrm{min}$ flow speed was preferred. At $263 \mathrm{~nm}$, the response of the TEC and CRH was greater. Therefore, $263 \mathrm{~nm}$ was deemed an appropriate wavelength for TEC and CRH quantification.

In part due to linear values, the linearity of calibration displays for TEC and CRH was verified by the large regression coefficient $\left(\mathrm{R}^{2}\right)$ values for the TEC and CRH $[18,27,28]$. The Ld values and Lq values of TEC and CRH met the sensitivity prerequisite for quantifiable analysis of TEC and CRH [19-21, 25-28]. The RSD measurements and percentage content assays of TEC and CRH confirmed the good preciseness and accurateness, respectively, of HPLC method proposed [19-26]. The recoveries of TEC and CRH validated the accuracy and selectivity of HPLC method proposed $[18,27$, 28]. When modifications to the robustness analysis were made, no major differences were noted. The robustness of the suggested HPLC approach is thus proven $[18,27,28]$.

The percentile degradation specified that the TEC is really sensitive than $\mathrm{CRH}$ to $0.1 \mathrm{~N} \mathrm{HCl}, 30 \%$ peroxide and dry heat degradation conditions executed. The stability of TRH is less than that of CRH under the sunlight and $0.1 \mathrm{~N} \mathrm{NaOH}$ degradation conditions executed as the percent recovery of TRH was less than CRH. Complete resolution of TEC and CRH peaks from its degradation-based compounds with no seeming shoulders confirmed the stability indicating feature and specificity of the suggested HPLC approach [17, 29-31].

Blank chromatogram showed no any peaks at retention times of TEC and CRH. While peak retention times for TEC and CRH was almost similar in the Cypro T sample chromatogram and TEC and CRH solution chromatogram. Thus, suggested HPLC approach selectivity was verified [18-26]. The system suitability measurements like plate counts, tailing symmetry, resolution, retention time and peak areas for the TEC and CRH peak fall within the ICH prescribed criterion, indicating appropriateness of HPLC instrumentation for assay of TEC and CRH combination by suggested approach $[18,27,28]$.

\section{CONCLUSION}

A "high-performance liquid chromatography" process for determining the combination of TEC and CRH in the syrup form and pure form has been described in the established method. The present "high-performance liquid chromatography" process is exemplified by its speed, ease and relatively inexpensive. The successful validity criteria of the proposed approach permit its use in laboratories for quality control.

\section{ACKNOWLEDGEMENT}

The Authors thank Rainbow Pharma Training Labs, Hyderabad, India for providing gift sample of tricholine citrate and cyproheptadine for the research project and providing the necessary support and infrastructure to conduct the experimentation.

\section{FUNDING}

Nil

\section{AUTHORS CONTRIBUTIONS}

All authors have contributed equally.

\section{CONFLICTS OF INTERESTS}

Nil

\section{REFERENCES}

1. Columbo M, Rohr AS. Asthma in the elderly: the effect of choline supplementation. Allergy Asthma Clin Immunol 2016;12:15.

2. Mehedint MG, Zeisel SH. Choline's role in maintaining liver function: new evidence for epigenetic mechanisms. Curr Opin Clin Nutr Metab Care 2013;16:339-45.

3. Tricholine citrate, Pubchem. Available from: https://pubchem.ncbi.nlm.nih.gov/compound/Tricholinecitrate [Last accessed on 20 Dec 2020]

4. Feng YM, Feng CW, Chen SY, Hsieh HY, Chen YH, Hsu CD. Cyproheptadine, an antihistaminic drug, inhibits the proliferation of hepatocellular carcinoma cells by blocking cell cycle progression through the activation of P38 MAP kinase. BMC Cancer 2015;15:134.

5. Kapur S, Zipursky RB, Jones C, Wilson AA, DaSilva JD, Houle S. Cyproheptadine: a potent in vivo serotonin antagonist. Am J Psychiatry 1997;154:884.

6. Harrison ME, Norris ML, Robinson A, Spettigue W, Morrissey M, Isserlin L. Use of cyproheptadine to stimulate appetite and body weight gain: a systematic review. Appetite 2019;137:62-72.

7. Ascierto PA, Marincola FM. Combination therapy: the next opportunity and challenge of medicine. J Transl Med 2011;9:115.

8. Ioannis Z. Improving cancer combination therapy by timing drug administration. Sci Transl Med 2020;12:eabb5671.

9. Fares J, Kanojia D, Rashidi A, Ulasov I, Lesniak MS. Landscape of combination therapy trials in breast cancer brain metastasis. Int J Cancer 2020;147:1939-52.

10. Tsioufis K, Kreutz R, Sykara G, van Vugt J, Hassan T. Impact of single-pill combination therapy on adherence, blood pressure control, and clinical outcomes: a rapid evidence assessment of recent literature. J Hypertens 2020;38:1016-28.

11. Cyprosal, Indiamart.com. Available from: https://www.indiamart.com/proddetail/cyproheptadine-withtricholine-citrate-syrup-15212352255.html [Last accessed on 20 Dec 2020]

12. Cyprohar, Indiamart.com. Available from: https://www.indiamart.com/proddetail/cyprohar16212742633.html [Last accessed on 20 Dec 2020]

13. Cyprolac $\mathrm{T}$, Indiamart.com. Available from: https://www.indiamart.com/proddetail/cyproheptadine-hcland-tricholine-citrate-syrup-21597816088.html [Last accessed on 20 Dec 2020]

14. Cypro $\mathrm{T}$, Indiamart.com. Available from: https://www.indiamart.com/proddetail/cyproheptadinehydrochloride-tricholine-citrate-syrup-20411821091.html [Last accessed on 20 Dec 2020]

15. Clopex TC, Indiamart.com. Available from: https://www.indiamart.com/proddetail/cyproheptadine-hcland-tricholine-citrate-syrup-8837917048.html [Last accessed on 20 Dec 2020]

16. Mayuresh K, Shaheen NS, Lalit JP. Safety and efficacy of a combination of cyproheptadine and tricholine citrate: phase IV study. Ann Int Med Den Res 2018;4:1-5.

17. International conference on the harmonization. ICH Stability testing of new drug substances and products Q1A (R2); 2003.

18. International conference on the harmonization. ICH harmonized tripartite guideline. Validation of analytical procedures: Text and methodology Q2(R1); 2005.

19. Belal F, El-Din MKS, Tolba MM, Elmansi H. Micelle-enhanced spectrofluorimetric method for determination of cyproheptadine hydrochloride in tablets: application to in vitro drug release and content uniformity test. J Fluoresc 2014;24:85-91.

20. Wagh YB, Bhushan BA, Saudagar RB. Development and validation of UV spectrophotometric method for estimation of cyproheptadine hydrochloride in bulk and tablet formulation by co-solvency approach. World J Pharma Res 2016;5:1924-30.

21. Sayanna VT, Reddy ChVR. Determination of cyproheptadine hydrochloride in pure and pharmaceutical forms: a spectrophotometric study. Orient J Chem 2015;31:1779-86.

22. Maham M, Kiarostami V, Waqif Husain S, Abroomand Azar P, Tehrani MS, Khoeini SM, et al. Extraction and determination of cyproheptadine in human urine by DLLME-HPLC method. Iran J Pharm Res 2013;12:311-8.

23. Sadhana JR, Mansi AS. New bioanalytical HPLC method for the determination of cyproheptadine hydrochloride in human plasma and its application to rat pharmacokinetic study. Indian J Pharm Educ Res 2019;53(Suppl 2):S338-46.

24. Mina M, Mahnaz Q, Seyed SH, Azade S. Preconcentration and determination of cyproheptadine by using liquid phase microextraction and solvent bar in biological fluids in trace level. Biosci Biotechnol Res Asia 2015;12:521-9.

25. El-Din MKS, Belal F, Tolba MM, Elmansi H. Stability indicating HPLC method coupled with fluorescence detection for the determination of cyproheptadine hydrochloride in its tablets. Studies on degradation kinetics. Anal Chem Lett 2018;8:565-77.

26. Feas X, Ye L, Hosseini SV, Fente CA, Cepeda A. Development and validation of LC-MS/MS method for the determination of 
cyproheptadine in several pharmaceutical syrup formulations. J Pharm Biomed Anal 2009;50:1044-9.

27. Ravichandran V, Shalini S, Sundaram KM, Rajak H. Validation of analytical methods-strategies and importance. Int J Pharm Pharm Sci 2010;2:18-22.

28. Rode DM, Rao NN. A review on development and validation of stability indicating HPLC methods for analysis of acidic drugs. Int J Curr Pharm Res 2019;11:22-33.

29. Rajasingam R, Sagineedu SR, Tan YH, Nalaiya J, Pichika MR. Stress degradation studies and development of a validated RP-
HPLC method for determination of tiagabine in presence of its degradation products. Int J Pharm Pharm Sci 2016;8:230-6.

30. Rao PVL, Rao A, Svum P. Development and validation of new stability indicating reversed-phase high-performance liquid chromatography method for simultaneous determination of metformin hydrochloride and ertugliflozin in bulk and pharmaceutical dosage form. Asian J Pharm Clin Res 2019;12:235-40.

31. Sharma S, Goyal S, Chauhan K. A review on analytical method development and validation. Int J Appl Pharm 2018;10:8-15. 